\title{
結晶構造解析用微小結晶作成装置
}

\section{A Device of Making Small Crystal Pieces for Structure Analysis}

\section{溝 田 忠 人 (Tadato Mizota)*}

$\mathbf{X}$ 線結晶構造解析は, 近年単結晶自動回析計や, 大型電子計算機の発達に より, 精度の向上がいちじるしい。しかし, 従来から回析強度測定のうえで 難問題の 1 つである “吸収補正”は，さほど進歩していない。計算機を用い て, 多面体近似の補正をやる他には，円柱状加球状の結晶をつくる以外には なく, 特に鉱物分野の結晶は, 試料の良いむのが得にくいととから, 普通は, 鉱物を適当にくだいて，不規則な形の結晶の中からいわ切る“良い形”をし た小さな（径 $1 / \mu$ 程度の）結晶をひろい出して，吸収を考慮せずに解析した り, 形を無視した球体近似補正をする場合が多いようである。とにかく，吸 収補正をおてなうには, 結晶軸に関して正しく切り出された多面体結晶か, できるならば，球状単結晶を得たいと思うのは，多くの研究者の望みであろ う。今後ますます高い精度を要求されると考える時，吸収補正を正碓におと なうということはどうしても解決しなければならない問題である。

最近, 硫化鉱物の $0.1 \sim 0.2 \mathrm{~mm}$ の角柱状または立方体状の単結晶を切り 出す装置を試作し, 初歩的な実験注いて, かなり良い結果を得たととと, 従来からむちいられてきた, Bond の空気流吹きてみ型の球状結晶作成装置 を改良して，てのマイクロカッターによって切り出した小結晶を研磨し，球 飞近い結晶を得られるようになった。

硫化鉱物は，比較的やわらかく，䢃開もあり，小結晶を得るためにくだく 之，X線解析には不向きな形となることが多い。また晶洞に成長した良い形 の結晶む得にくい。しかし，反射顕微鏡下で普通の鉱石を篗察すると，かな り大きく成長した単結晶む見られる場合があり，乙れを切り出すことが重要

* 新潟大学理学部地質鉱物学教室 
である。切り出す場合に $1 \sim 2 \mathrm{~mm}$ 程度の同一の単結晶から多くの小結晶を 切り出すことができれば，同一の試料で， X線マイクロアナライザーによる 化学分析, 物性测定, 加熱による相転移の研究などにも使用できて, 非常に 有効であろう。硫化鉱物結晶は，珪酸塩鉱物などにくらべれば “こわれやす い”ので，あまり力を加えずに切り出したい。そこで次のようなお法をとっ た。

\section{マイクロカッターについて}

第 1 図および第 2 図は，その装置である。原理は，普通の交流電源を利用 して，振動磁場をつくり，そのそばに，“はがね”のリボンを置き振動させ， その振動をカッターの歯に伝えて結晶を切るのである。結晶は，強い力が加 わらないために，シーソー型のバランスの一方に固定しておき，他方の重り を加減するととによって，歯への圧力を制御する。との装置では， $0.5 \mathrm{~V} の$ 電原のわずかな振動により 1 時間以内で 1〜2 $m m$ の深さに切ることができ

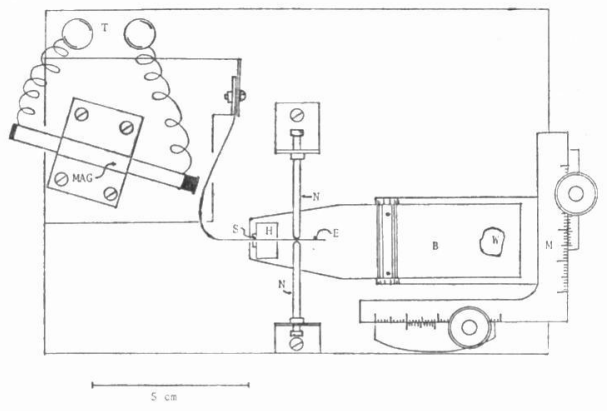

第1図マイクロカッター $\mathrm{T}$ ：ターミナル。 MAG：マグネット。 $\mathrm{S}$ : 試料。 $\mathrm{H}$ : 試料支持台。 $\mathrm{N}$ : 横プレ防止ボルト。 $\mathrm{E}$ : カッター; 時計ゼンマイを成形し, 試料を切る 部分は，ガラス板か力ミソリの歯在はりつけて おく。B：切断圧力バランス，シーソー型にな っていて，支点は，ず机ないように2 個所のく ぼみを下からささえている(図中の 2 つの黒点)。 $\mathrm{W}$ : バランス重り，ゴム粘土をのせている。 $\mathrm{M}$ ： メカニカルステーシ，試料老微小に平行移動さ せたり，摩滅した歯の部分からずらせるために あちいる。
る。歯の前後への振動は $1 \mathrm{~mm}$ 以下である。蔝の材質は，硫化 鉱物程度の硬さには, 安全力ミ ソリの窲（約 $0.1 \mathrm{~mm}$ 幅，斜め に研いである部分はけずりとる) か，岩石薄片用のデッキグラス (約 $0.15 \mathrm{~mm}$ 幅) が良い。歯之 結晶の間には， =1000のカーボ ランダム粉末を機械油にといた ものを，5分間に 1 湖程度たら してやる。結晶在一定閒隔に切 るために，シーソ一型武料保持 板を，顕微鏡用のメカニカルス テージに國定している。このよ うにして, 岩手罧大峰鉱!鷹中 ュ一バ鉣走切ったのが，第 3 図 である。切る面は，1２ $\mathrm{mm}$ 角 に研磿し，角柱にして方き，と 


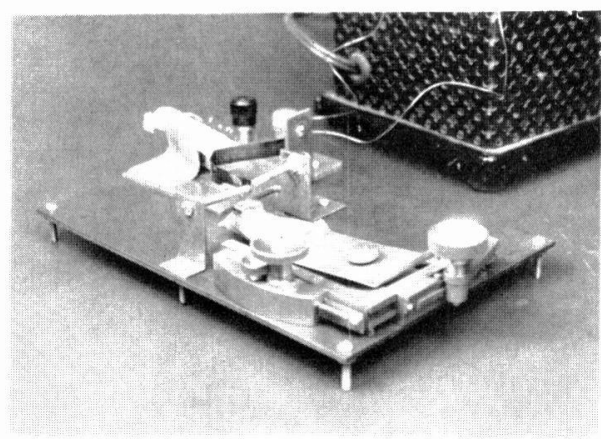

第 2 図マイクロカッター, 徯方はスライ ダック。

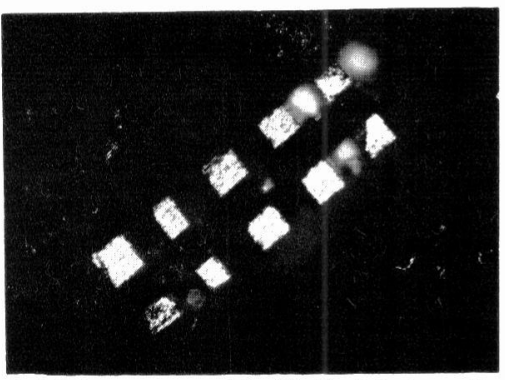

節 3 図キューバ鉱 $\left(\mathrm{CuFe}_{2} \mathrm{~S}_{3}\right)$ に一方 向汇 4 本，乙扎上直交して 1 本切 b)湛在人机たとこ万。武料約 0.6 $m m \times 1.8 \mathrm{~mm}$, 淇幅約 $0.2 \mathrm{~mm}$.

れをサイコロ人の岩不片にのりで国定し，こ扎在，試料保持バランスの一う

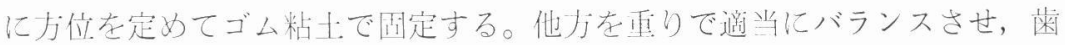

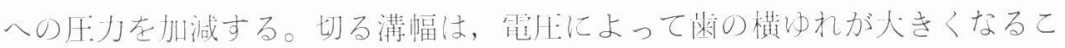

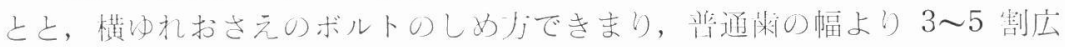
くなる。デッキガラス在用いた埸合 $0.5 \mathrm{~V}$ の振動で $0.2 \sim 0.25 \mathrm{~mm}$ 幅の溝

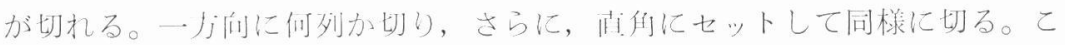

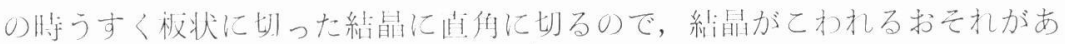

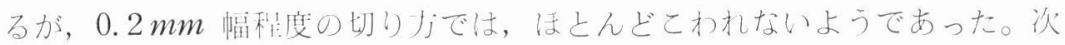

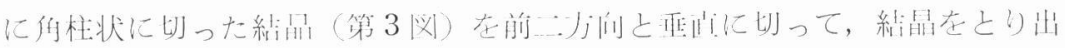

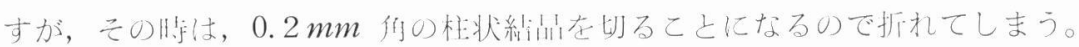

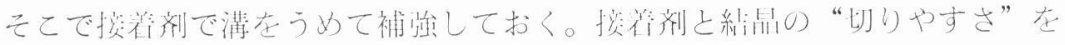

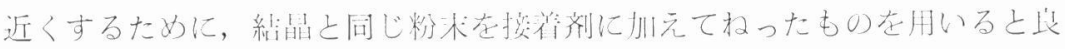
い絊果か待ら机た。损存剂は，後から溶剂でとかしさることができて，あつ

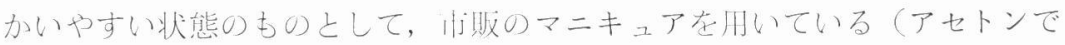

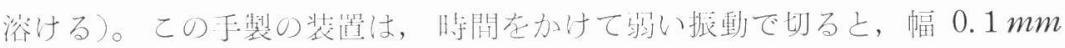
に切り出すことは己う困難ではないが，今つかっているメカニカルステージ の粘度が良くないので，再現州がわるく，切り出し精度はあまり良くない。 しかし，同一の $2 \mathrm{~mm}$ 角の結晶から 25 湖以上の小結晶在切り出せるので中 には，目的とした形と大きさのむのができるようである。

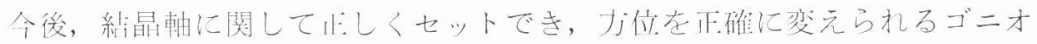
メーター在つくって, このマイクロカッター在もちい机代, 球状にしなくて 


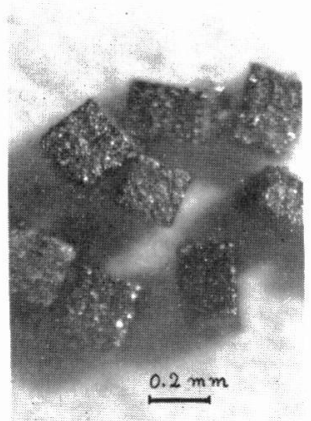

第4図第3四の八本の角柱老紙面 に平行に切り出したすの。

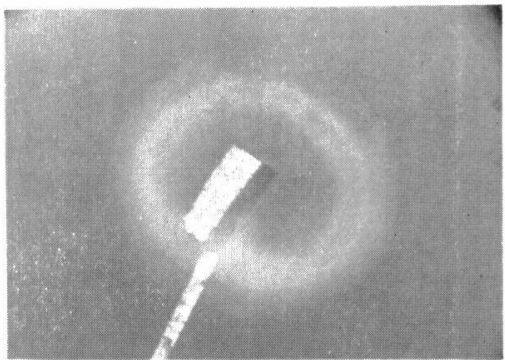

筑 5 図四角柱 $0.2 \times 0.2 \times 0.4 \mathrm{~mm}$ 亿切? 出しガラス棒にセットした去ューバ鉣。

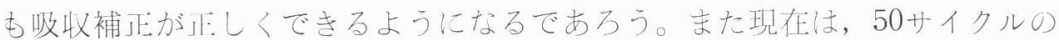
交流振動をちいているが，周波数在コントロールし，蔽として，もっ上硬 いもの在使えば，珪酸塩鉱物も切狆るようになるであ万う。第 4 四に切り出

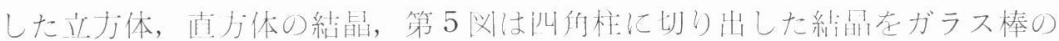
允にセットしたすの在小す。

\section{Bond の球状結晶作成装置の改良について}

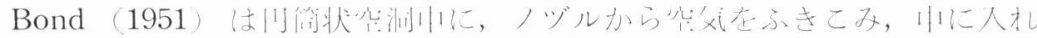

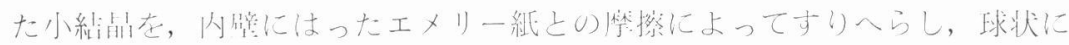

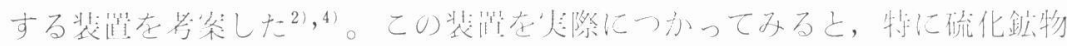
などでは，次のような㳸高がある。

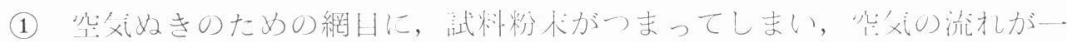
椂につつかかない。特に一度に多くの试料老人扎ると，このことがはなはな

しく，また小さな試料が網目にひっかかって，うまく山怡しない。

(2) 武料の状態が，ふた在るけて子ない上わからず，武料の回転状態上，ど の程度まるくなったかがわからない。

(3)エメリーペーパーが奏際には、はりにくく，すきまに絬品がはりこえで 研磨されない。

等である。この装置在用いて梂形にするにはできるだけ球状在した綃萌在

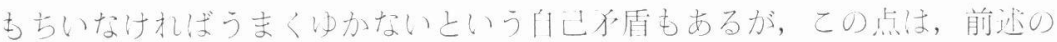




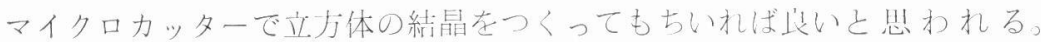

Bond の装管は，その後， Senio and Tucker $(1953)^{6)}$, Bond $(1954)^{3)}$,

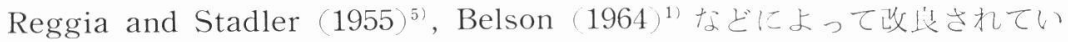
るが，ほとんど磁性测定が目的の武料つくりで，X緗问折朋には，絬晶球が

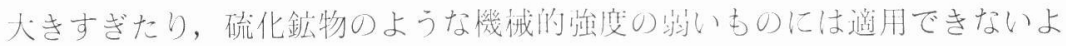
うに焽才れる。

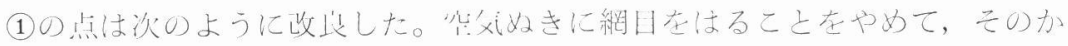

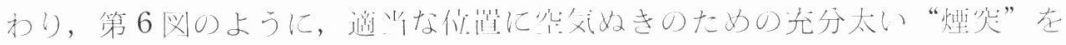
立てる。武料はたとえ烟穴り川にはいっても, そこでは空父流速が遅いので, 下の研杯空润にもどる。このようにす ると網目がつまることもなく，また， (2)について，ガラス板で光食に前血に ふた在することができるので，以简内

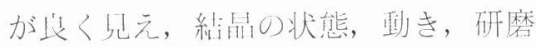

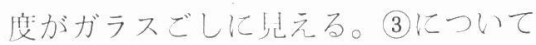
は，挍倠剂にといた所禁剂粉末在门简 队面にうすく好る方法が一番よかった。 一j, コンプレッサーで, ノズルから 热父在炊き込むには，普通のコンプレ ッサーでは容量が大きすぎ，大部分の 公父は不要であるし，流量調邻もめん どうである。そこで，ことでは，“燸 笑”にゴムホースをつないで，逆にア スピレーターで吸引してみた。この装 犆では，ノズル分しか朋いていないの でアスピレーター0流水是圭邀当に すると，ノズルから橆が流入し，絬 晶がうまく四転した。この装㳻で作っ たキューバ鉣の絬晶在符 7 刚に示した。 力ッターの糊度加悲々, 正しい立才体 にならなかったととから桲円体に近い ようであるが, かなり梂形のむのあで

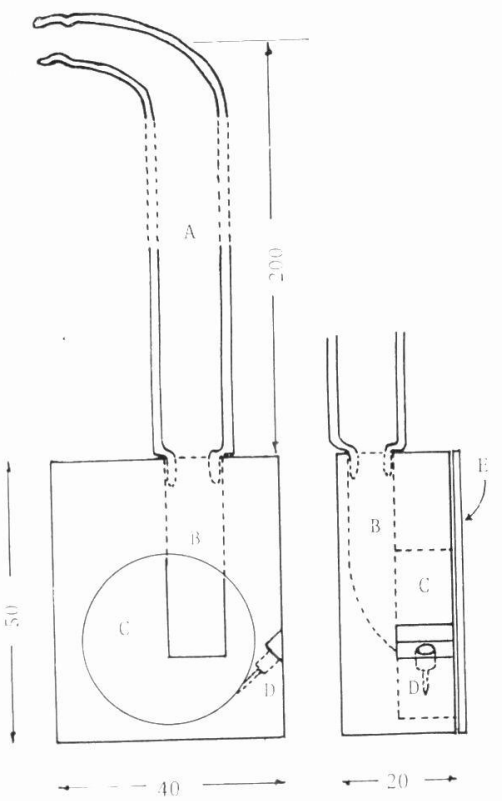

第 6 図 Bond の装置在改良した吸引型 装置 A : “煙突” (ガラス管) 先端在ア スピレーターにつなぐ。B：研磨円筒 Cから空気を好く溝, 結晶がひっかか ってあす心゙り捄ちるようにテーパーを つけておく。C：研磨四筒部。D：， ズル穴，先端は径 $1 \mathrm{~mm}$ ，その後方圭 径 3 mm飞くってある。 $\mathrm{E}$ ：ガラス板 のふた，金属でできた䀒磨円简部之は ンゴムパンドて湖主。 


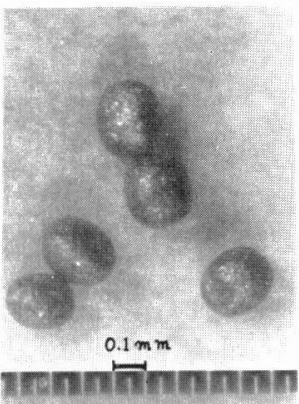

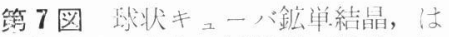
じめは，あらい減磨剂で球状にし， 後に げたもの。

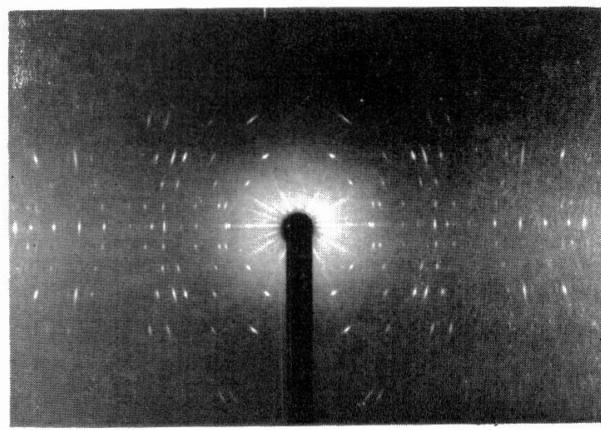

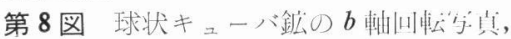
$\mathrm{CoK} \alpha, \mathrm{Fe}$ filter.

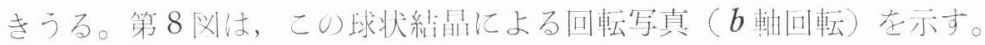

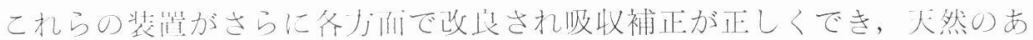

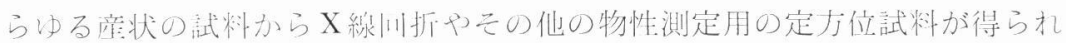
るようになるとと在趶む。 (1971年. 7 月26日受理)

\section{文献}

1) Belson, H. S. (1964) : Sphere Grinding and Polishing, Rev. Sci. Instrum. 35, 234-236.

2) Bond, W. L. (1951) : Making Small Spheres, Rev. Sci. Instrum. 22, 344-345.

3 . (1954) : Making Crystal Spheres, Rev. Sci. Instrum. 25, 401.

4) 罗崎 博 (1969): 球状の单結晶の作製, 日本絬晶学会誌, 11, 183-186.

5) Reggia, F. and Stadler, W. (1955) : Ferrite Sphere Grinder, Rev. Sci. Instrum. 26, 731-732.

6) Senio, P. and Tucker, C. W. Jr. (1953) : Ceramic Wheel Sphere Grinder, Rev. Sci. Instrum. 24, 549 . 